\title{
Monoclonal antibodies against Bonamia ostreae (Protozoa: Ascetospora), an intrahaemocytic parasite of flat oyster Ostrea edulis (Mollusca: Bivalvia)
}

\author{
Hervé Rogier ${ }^{1}$, Dominique Hervio ${ }^{2}$, Viviane Boulo ${ }^{2}$, Christine Clavies $^{1}$, \\ Eliane Hervaud ${ }^{1}$, Evelyne Bachère ${ }^{2}$, Eric Mialhe $^{2}$, Henri Grizel $^{2}$, Bernard Pau ${ }^{3}$, \\ Francis Paolucci ${ }^{1}$ \\ ${ }^{1}$ Sanofi Recherche, Rue du Professeur, Blayac, F-34082 Montpellier, France \\ ${ }^{2}$ IFREMER, Unité de Recherches en Pathologie, Immunologie et Génétique Moléculaire (URPIGM), B.P. 133, \\ F-17390 La Tremblade, France \\ ${ }^{3}$ Faculté de Pharmacie, Avenue Charles Flahault, F-34060 Montpellier Cedex, France
}

\begin{abstract}
A.BSTRACT: The protozoan Bonamia ostreae (Ascetospora), a parasite of the flat oyster Ostrea edulis, was purified by differential and isopycnic centrifugations. Mice of the strain Balb/c were immunized with purified parasites and hybridomas were prepared by fusion of immunized mouse splenocytes with the mouse myeloma cell line P3-X63-Ag8-653. From the fusion, 12 clones were isolated and saved. The resulting antibodies were characterized with a solid phase radioimmunoassay (RIA). Antibodies from 7 clones reacted only with $B$. ostreae and not with normal host tissue. Although some of the antibodies appeared to react with the same epitopes, at least 4 clearly different epitope specificities were identified. One of these antibodies (20B2-1B12) had an apparent association constant of ca $3 \times 10^{8} \mathrm{M}^{-1}$ and bound to a number of different sites on the parasite. These monoclonal antibodies should prove to be of great value as diagnostic and research tools.
\end{abstract}

\section{INTRODUCTION}

The protozoan Bonamia ostreae (Ascetospora) is responsible for hemocyte disease of the flat oyster Ostrea edulis (Pichot et al. 1980). The parasite is ca $3 \mu \mathrm{m}$ in diameter and replicates within the parasitophorous vacuoles of the host hemocytes. Infected cells die and liberate additional parasites into the vascular system. Bonamiasis is characterized by branchial ulceration and the accumulation of hemocytes in focal areas of the connective tissue. The disease is usually fatal causing a high mortality rate in a population within 6 mo of infection. Transmission of the disease occurs throughout the year, probably resulting from the continuing liberation of parasites from the tissues of dying and dead oysters (Grizel 1985).

Bonamiasis was first described in south Brittany (France) and since 1979 has spread to numerous oyster farming areas in France, England (Bannister \& Key
1982), Holland (Van Banning 1982) and Spain (Polanco et al. 1984). The disease was also recently reported in association with serious oyster mortalities in Ireland (McCardle pers. comm.). The loss of production due to bonamiasis varies in different countries, but the mortality rate can be as high as $90 \%$. Recently, the disease was described in North America (Elston et al. 1986 Farley et al. 1988). In addition, a similar but morphologically different parasite was found associated with mass mortalities of the New Zealand dredge oyster Tiostrea lutaria (Dinamani et al. 1987). To guarantee the continuity of oyster farming in several areas of the world, it is essential to develop methods for the prevention and management of bonamiasis. In the absence of oyster strains resistant to the disease, as well as effective treatment methods, it is necessary to develop immunodiagnostic procedures which will support strategies for the management of bonamiasis.

We describe here the production of monoclonal anti- 
bodies against Bonamia ostreae. The specificity and affinity we observed for certain of these antibodies will be useful in specific immunodiagnostic tests and as research tools.

\section{MATERIALS AND METHODS}

Organism and purification system. Healthy oysters Ostrea edulis were obtained from the 2 Bonamia ostreae free oyster culture sites in France: Thau Pond (Mediterranean), and natural oyster beds of Belle-Isle (Brittany). These oysters were kept in the laboratory several months before use.

Parasitized oysters were dredged from the Bay of Quiberon (Brittany) where bonamiasis has been enzontic for several years.

Bonamia ostreae was purified from parasitized oysters by differential and isopycnic centrifugations (Mialhe et al. 1988). Purified B. ostreae parasites were washed with sterile seawater by centrifugation $(2000 \times g, 30 \mathrm{~min})$ in order to remove residual Percoll, and then resuspended in seawater to a concentration of $2 \times 10^{6}$ cells $\mathrm{ml}^{-1}$. Electron microscopic examination of purified parasites verified the structural integrity of the purified organisms but also indicated the presence of fragments of host membranes on the parasite surface. These membranes are thought to represent portions of parasitophorous vacuole membranes from the host cell.

A single healthy oyster was selected for observation at the laboratory for several weeks and examined histologically to confirm the absence of bonamiasis. This oyster was homogenized with an Ultra-Turrax homogenizer in $500 \mathrm{ml}$ of sterile seawater. The homogenate was passed through a 25 um mesh sieve and $100 \mu \mathrm{l}$ were plated into each well of a microtiter plate and treated as described in hybridoma screening procedures.

Immunization protocol. Six mice (Balb/c) were immunized by initial intraperitoneal (i.p.) $(500 \mu l)$, intravenous (i.v.) $(100 \mu \mathrm{l})$ and intramuscular $(100 \mu \mathrm{l})$ injections of purified parasite suspensions $\left(10^{7}\right.$ parasites $\mathrm{ml}^{-1}$ ) diluted with one part complete Freund's adjuvant to 3 parts parasite suspension. Six subsequent i.p. injections without adjuvant were made at monthly intervals. The mouse with the highest serum titer was reinjected i.v. with $200 \mu \mathrm{l}$ of parasite suspension at a concentration of $10^{7} \mathrm{ml}^{-1}, 3 \mathrm{~d}$ before the lymphocyte hybridization.

Lymphocyte hybridization protocol. The myeloma cell line P3-X63-Ag8-653 was cultived in RPMI 1640 medium (Gibco laboratories) containing 10\% heatinactivated fetal calf serum and $1 \mathrm{mM}$ glutamine Spleen cells were fused with the myeloma line by a method adapted from French et al. (1986): splenocytes and myeloma cells were washed and suspended in a serum-free medium. For each fusion, $3 \times 10^{8}$ splenocytes and $1.5 \times 10^{8}$ myeloma cells were mixed and centrifuged at $200 \times g$ for $10 \mathrm{~min}$ at room temperature.

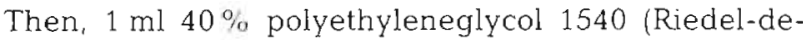
Haën AG, Seelze, Hannover, Germany) was added to the cell pellet dropwise over $30 \mathrm{~s}$ with gentle stirring. After 1 min at $37^{\circ} \mathrm{C}$ the cells were pelleted by centrifugation at $300 \times g$ for $1.5 \mathrm{~min}$ and incubated for another $2 \mathrm{~min}$ at $37^{\circ} \mathrm{C}$. The pellet was then diluted to $15 \mathrm{ml}$ by the addition of serum-free medium (the first $5 \mathrm{ml}$ was added over $5 \mathrm{~min}$ ). Cells were centrifuged at $150 \times \mathrm{g}$ for $10 \mathrm{~min}$, resuspended in the medium containing $15 \%$ fetal calf serum and distributed $\left(0.1 \mathrm{ml} \mathrm{well}^{-1}\right)$ into microculture plates (microplates with $10^{5}$ cells well ${ }^{-1}$ and microplates with $2 \times 10^{5}$ cells well $^{-1}$ ) containing macrophages as feeder cells $\left(5 \times 10^{3}\right.$ Balb/c peritoneal cells per $0.2 \mathrm{ml}$ well ${ }^{-1}$ ). One day after the fusion, hybridomas were selected by adding $0.1 \mathrm{ml}$ well $^{-1}$ of double-concentrated hypoxanthineaminopterin-thymidine medium (HAT) (hypoxanthine, $10^{-4} \mathrm{M}$; aminopterin, $4 \times 10^{-7} \mathrm{M}$, thymidine, $1.6 \times$ $10^{-5} \mathrm{M}$ ). Four and $7 \mathrm{~d}$ after lymphocyte hybridization, $100 \mu \mathrm{l}$ of culture supernatant was replaced in each well with fresh normal HAT medium. The frequency of cultures with growing hybrid cells, analyzed according to Poisson's distribution (Paolucci et al. 1986), was determined after 7,9 and $14 \mathrm{~d}$ culture by visual examination with an inverted phase microscope.

Hybridoma screening procedures. The 2 screening tests were indirect solid phase radioimmunoassay (RIA). The control screening test was performed in an identical manner to the positive screening test, except that Bonamia ostreae was replaced, in each well, by non-infected oyster homogenate.

The positive screening test was performed with Bonamia ostreae as follows: cells were seeded $\left(2 \times 10^{5}\right.$ per $100 \mathrm{ul} \mathrm{well^{-1 }}$ ) in microtiter plates which had been pretreated with poly-L-lysine $\left(20 \mu \mathrm{g} \mathrm{ml}^{-1}, 50 \mu \mathrm{l}\right.$ well ${ }^{-}$. $30 \mathrm{~min}, 37^{\circ} \mathrm{C}$ ) to enhance the absorption of $B$. ostreae cells. Afterwards, the plate was centrifuged $(2000 \times g$, $30 \mathrm{~min}$ ), and the parasites were fixed with glutaraldehyde $10.5 \%$ in phosphate buffer saline [PBS], $20 \mu \mathrm{l}$ well ${ }^{-1}, 8 \mathrm{~min}, 20^{\circ} \mathrm{C}$ ) and washed carefully with PBS. Finally, the plates were filled with PBS-BSA (Bovine serum albumine) (2\% BSA, $0.75 \%$ glycine, $200 \mu \mathrm{l}$ well ${ }^{-1}, 30 \mathrm{~min}, 20^{\circ} \mathrm{C}$ ) and stored at $-20^{\circ} \mathrm{C}$ until use.

When needed, the plates were thawed and washed 3 times with PBS. Each hybridoma culture supernatant $(50 \mu \mathrm{l})$ was diluted with an equal volume of Buffer $\mathrm{C}$ (PBS, 5\% BSA, 0.5\% Tween 20) and placed in one well of Bonamia ostreae cells and one well of healthy oyster homogenate for incubation $\left(2 \mathrm{~h}, 37^{\circ} \mathrm{C}\right)$. After 3 washes 
(150 $\mathrm{mM} \mathrm{NaCl}, 0.5 \%$ Tween 20), an anti-mouse sheep IgG (Diagnostic pasteur), conjugated with ${ }^{125}$ I by oxidation with chloramine $\mathrm{T}$ (Butt 1984) and diluted in Buffer $\mathrm{C}$ to $3 \times 10^{6} \mathrm{cpm} \mathrm{ml}^{-1}$, was incubated in each well $\left(100 \mu \mathrm{l}\right.$ well $\left.^{-1}, 1 \mathrm{~h}, 37^{\circ} \mathrm{C}\right)$. Following incubation and 5 washes, the radioactivity of each well was measured with a gamma counter (Kontron).

Production and purification of monoclonal antibodies (MAbs). After cloning by the limiting dilution method, $2 \times 10^{6}$ hybridoma cells from the selected clones were injected i.p. into mice $(\mathrm{Balb} / \mathrm{c})$. The mice had been injected $15 \mathrm{~d}$ before with $500 \mu \mathrm{l}$ of pristane (Sigma, ref. T 7640) to avoid developing a solid tumor. About $2 \mathrm{wk}$ after injection of hybridoma cells, the ascite fluids containing MAbs were punctured and clarified by centrifugation. The monoclonal antibodies were then purified by affinity chromatography with Protein-A-Sepharose (Pharmacia). Isotypes and isoelectric points of purified antibodies were identified by the Ouchterlony and electrofocusing methods.

Specificity of monoclonal antibodies. The specificity of the selected MAbs was tested by direct solid phase RIA on nitrocellulose. Purified antibodies were radiolabelled with ${ }^{125} \mathrm{I}$ as described earlier. The specific binding activity of the antibodies was tested as follows Ten microliters of each type of antigen (either purified parasite suspensions or hemolymph from healthy oysters) was absorbed onto a $6 \mathrm{~mm}$ diameter nitrocellulose discs placed in a microtiter well for $15 \mathrm{~h}$ at $37^{\circ} \mathrm{C}$. The nitrocellulose discs, which were subsequently dried, were then incubated $\left(2 \mathrm{~h}, 37^{\circ} \mathrm{C}\right)$ in $100 \mu \mathrm{l}$ of gelatin (5 $\mathrm{mg} \mathrm{m}^{-1}$ in $100 \mathrm{mM}$ phosphate buffer at $\mathrm{pH} 7.4$ ) in a microtiter well. After 3 washes (NaCl $100 \mathrm{mM}$ ), $100 \mu \mathrm{l}$ of phosphate buffer (100 mM) with $5 \%$ gelatin containing the radiolabelled MAbs $\left(100 \mathrm{ng} \mathrm{ml}^{-1}\right.$ and $2.5 \times 10^{6}$ $\mathrm{cpm} \mathrm{ml} \mathrm{m}^{-1}$ ) was incubated in each well for $3 \mathrm{~h}$ at $37^{\circ} \mathrm{C}$. The radioactivity of the filter discs was determined after 5 washes with $100 \mathrm{mM} \mathrm{NaCl}$.

The specificity was confirmed by indirect RIA. The protocol was identical to the direct RIA method with the addition of an incubation $\left(1 \mathrm{~h}, 37^{\circ} \mathrm{C}\right)$ in radiolabelled rabbit anti-mouse serum $\left(2.5 \times 10^{5} \mathrm{cpm} 100 \mu \mathrm{l}^{-1}\right.$ in 100 mM PBS, $5 \%$ gelatin at $\mathrm{pH} 7.4$ )

Differentiation of monoclonal antibodies. Differentiation of the anti-Bonamia ostreae MAbs was accomplished by competing each radiolabelled antibody with a non-labelled antibody. The protocol was identical to the direct solid-phase RIA on nitrocellulose with B. ostreae, except that the labelled MAbs (120 ng $\left.\mathrm{ml}^{-1}\right)$ were simultaneously incubated with a 100-fold excess of non-labelled MAbs $\left(12 \mu \mathrm{g} \mathrm{ml}^{-1}\right)$.

Affinity of monoclonal antibodies. The apparent equilibrium association constant, $k$, was determined by direct solid phase RIA on nitrocellulose with parasitized oyster hemolymph and purified Bonamia ostreae. Assays were performed exactly as described for complementarity test except that different concentrations of non-labelled 20B2-1B12 were used to inhibit the fixation of a constant amount of ${ }^{125} \mathrm{I}$ labelled $20 \mathrm{~B} 2$ $1 \mathrm{~B} 12$.

\section{RESULTS}

\section{Immunization of mice}

Following the 6 immunizations, the serum of each mouse was evaluated by the hybridoma screening method. These sera contained antibodies directed against non-infected oyster cells and Bonamia ostreae. The mouse which had the best specific immunologic activity against Bonamia ostreae was given a last immunization $3 \mathrm{~d}$ before the fusion. The antibody titer of this mouse was determined on the day of the fusion (Fig. 1). For a serum dilution of $1 / 1000$, the reactivity of the serum antibodies with normal cells of the oyster (control screening test) was 3 times stronger than with $B$. ostreae antigens (positive screening test). The results show that the normal oyster tissue is highly immunogenic to the mouse.

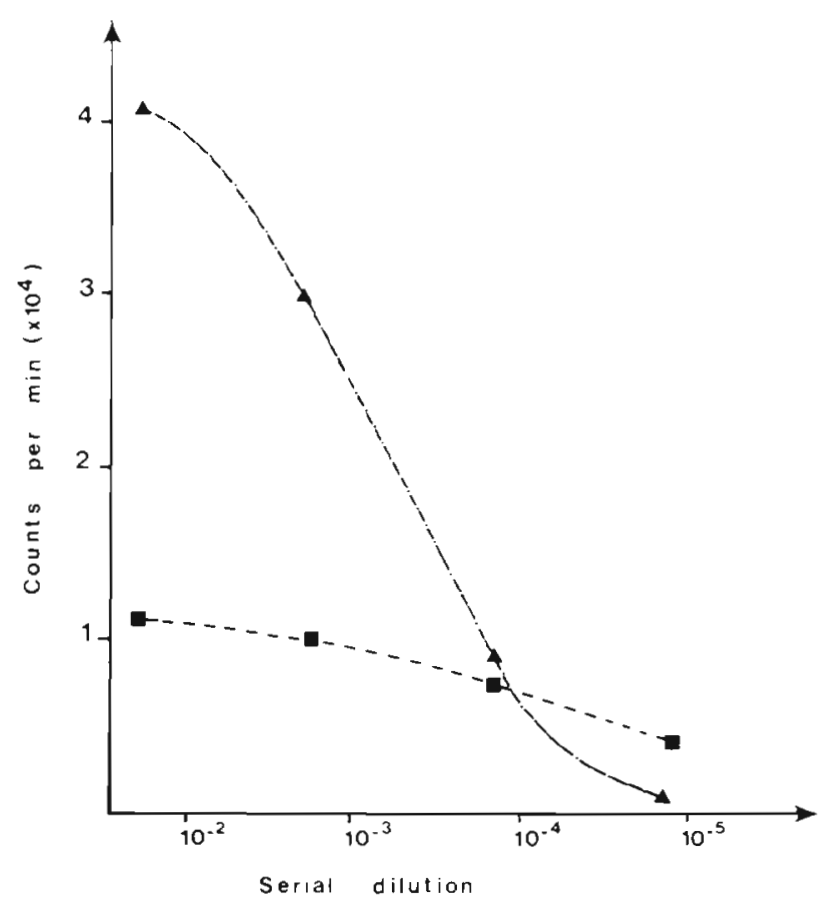

Fig. 1. Monoclonal antibodies against Bonamia ostreae Characteristics of immune serum of the mouse used for the lymphocyte hybridization. Test was performed with solid phase RIA in the presence of purified B. ostreae parasites ( $\mathbf{a}$ ) or normal oyster hemocytes ( $)$. Antibody reactivity with oyster cells or parasite was detected with a radiolabelled anti-mouse immunoglobulin antibody 


\section{Hybridoma production}

After $7 \mathrm{~d}$ culturing, from 1344 wells each receiving ca $10^{5}$ cells, 682 wells $(50.7 \%)$ contained one or more types of hybridoma cells. Using the Poisson analysis, 470 wells $(35 \%)$ should contain only one type of hybridoma, $162(12 \%)$ should contain 2 hybridoma types and $50(3.7 \%)$ should contain 3 types of hybridomas. In contrast, from 170 wells receiving an inoculum of $2 \times$ $10^{5}$ cells, we expected 138 wells $(81 \%)$ to contain one or more hybridomas. Only $54(31.5 \%)$ wells should contain a single hybridoma, $45(26.2 \%)$ wells should contain 2 hybridomas and $25(14.5 \%)$ wells should contain 3 or more hybridomas. These results show the importance of initially inoculating a larger number of wells with a relatively low number of cells $110^{5}$ per cell) The hybridomas recovered under these conditions were precloned.

In addition, 2 microplates were cultivated in the absence of macrophages. Out of 185 wells also receiving $2 \times 10^{5}$ cells, only $64(34,6 \%)$ wells contained one or more hybridomas, showing the determinant role of feeder cells in the hybridoma growth.

\section{Isolation of hybridomas producing anti-Bonamia ostreae antibodies}

In order to identify hybridomas producing specific antibodies against Bonamia ostreae, a 2-step screening test was used. This was necessary because of the difficulties in purifying large quantities of the parasites, and because of the presence of host membranes on the surface of the parasites. In the first step, the culture supernatants of the precloned hybridomas were tested against healthy oyster cells (control screening test); the strongly positive culture supernatants were eliminated. The other supernatants were subsequently analyzed by a second step against $B$. ostreae cells (positive screening test)

After 3 screenings, conducted 7, 9 and $14 \mathrm{~d}$ after the fusion, 166 wells (ca $24.3 \%$ ) contained antibodies reacting against normal oyster cells while 23 other wells $(3.4 \%)$ contained antibodies reacting specifically against Bonamia ostreae. These results are related to those for the serum of the mouse used for the fusion, which showed a strong antibody response against normal oyster antigens (Fig 1)

Subsequent cloning of 8 different Bonamia ostreae hybridomas allowed us to obtain 7 clones producing specific anti-B.ostreae antibodies as determined by indirect solid phase RIA (the positive screening test using $B$. ostreae cells). Antibodies from 3 other clones (16G5-2E7, 16G5-3D10 and 16F11-2A7) reacted strongly with $B$. ostreae but also to a lesser degree with oyster tissue.

Antibodies produced by these 10 clones were produced in ascite fluids, purified with Protein-A-Sepharose and characterized (Table 1)

\section{Specificity of purified antibodies}

Results for immunological and cellular specificities of 2 selected antibodies (20B2-1B12 and 15C2-2F2) are given in Fig, 2. The reactions of these 2 MAbs on purified parasites were only slightly inhibited in the presence of a 100 -fold excess $\left(12 \mu \mathrm{g} \mathrm{ml}^{-1}\right)$ of normal mouse immunoglobulin (Fig. 2A). The binding of radiolahelled antihody was almost totally extinguished in the presence of a 100 -fold excess $\left(12 \mu \mathrm{g} \mathrm{ml}^{-1}\right)$ of the homologous unlabelled antibody (Fig. 2A). The reaction of the radiolabelled monoclonal antibodies with the parasite is due to specific immunological recognition. The minimal reaction of the radiolabelled antibodies with the normal oyster tissue confirms the specificity of these antibodies for Bonamia ostreae (Fig. 2B).

Only 4 other MAbs retained their full activity after radiolabelling (10F1-2D4, 16G5-2E7, 16G5-3D10, 20B2-3A8). The specificities of 2 of the radiolabelled antibodies (10F1-2D4 and 20B2-3A8) are in all respects comparable (i.e. competed by the homologous nonlabelled antibodies and not reacting with normal oyster tissue) to the antibodies produced by Clones 20B2$1 \mathrm{~B} 12$ and $15 \mathrm{C} 2-2 \mathrm{~F} 2$, and display the characteristics shown in Fig. 2.

The 2 clones 20B2-1B12 and 20B2-3A8 originated from the same progenitor wells.

Radiolabelled antibodies 16G5-2E7 and 16G5-3D10 reacted with normal oyster cells and originated from

Table 1. Monoclonal antibodies against Bonamia ostreae. Immunological and biochemical characteristics of selected antibodies aigainst oyster parasite. For 2 hybridoma-clones these characteristics were not determined (ND)

\begin{tabular}{|llc|}
\hline Hybridoma-clone & Isotype & Isoelectric point \\
\hline $2 \mathrm{E} 31 \mathrm{~F} 2$ & $\operatorname{Ig~G1}$ & $6.7-7.2$ \\
$10 \mathrm{~F} 12 \mathrm{D} 4$ & Ig G1 & $6.5-7.0$ \\
$10 \mathrm{G} 92 \mathrm{D} 2$ & Ig G1 & $7.5-8.0$ \\
$15 \mathrm{C} 22 \mathrm{~F} 2$ & Ig G2a & $8.2-8.5$ \\
$16 \mathrm{G} 52 \mathrm{E} 7$ & Ig G2a & $6.3-6.6$ \\
$16 \mathrm{G} 53 \mathrm{D} 10$ & Ig G2a & $\mathrm{ND}$ \\
$16 \mathrm{~F} 112 \mathrm{~A} 7$ & Ig G1 & $7.0-7.3$ \\
$16 \mathrm{~F} 112 \mathrm{~F} 10$ & Ig G1 & $7.0-7.3$ \\
$20 \mathrm{~B} 21 \mathrm{~B} 12$ & Ig G2a & $6.9-7.3$ \\
$20 \mathrm{~B} 23 \mathrm{~A} 8$ & Ig G3 & $\mathrm{ND}$ \\
\hline
\end{tabular}


the same progenitor well. Four other clones (2E3-1F2, 10G9-2D2, 16F11-2A7 and 16F11-2F10) lost their immunoreactivity after radiolabelling.

The specificities of the antibodies were confirmed using an indirect RIA on nitrocellulose. Antibodies 2E31F2 and 10G9-2D2 specifically recognized Bonamia ostreae antigens. Antibodies 16F11-2A7 and 16F112 F10 also reacted with normal oyster cells and originated from the same progenitor well.

\section{Relative specificity of monoclonal antibodies}

Results of the test of relative specificity (Table 2) showed that the different radiolabelled antibodies recognized 4 different epitopes. Epitope I was recognized by the 2 antibodies from Clones 20B2-1B12 and 20B2$3 \mathrm{~A} 8$ which both originated from progenitor Clone 20B2. Epitope II was recognized by antibody from Clone $15 \mathrm{C} 2-2 \mathrm{~F} 2$. Epitope III was recognized by the 2 antibodies 16G5-2E7 and 16G5-3D10, which both originated from progenitor Clone 16G5. Epitope IV was identified only by antibody from Clone 10F1-2D4. These results indicate that antibodies produced by clones originating from the same progenitor well displayed the same characteristics and were probably identical.

The 4 antibodies which we could not radiolabel (2E3$1 \mathrm{~F} 2,10 \mathrm{G} 9-2 \mathrm{D} 2,16 \mathrm{~F} 11-2 \mathrm{~A} 7$ and 16F11-1F10) did not inhibit the reactivity of any of the radiolabelled antibodies against Bonamia ostreae. These 4 antibodies recognized different epitopes than those defined above (Epitopes I to IV).

\section{Affinity constant of Antibody 20B2-1B12}

The apparent association constant, $k$, of Antibody 20B2-1B12 was determined according to Scatchard representation (Walker 1977), with purified Bonamia ostreae (Fig. 3A) or with infected hemolymph (Fig. 3B). The $k$ values, $2.7 \times 10^{8} \mathrm{M}^{-1}$ and $3.9 \times 10^{8} \mathrm{M}^{-1}$ respectively, are not significantly different and show that the antibody is equally efficient in recognizing antigen on either purified parasites or in the hemolymph of the infected oyster. In addition, since the epitope number on each parasite can be calculated from the molar epitope concentration $(\mathrm{mc})$ with an estimated 200000 purified parasites per well (Fig. 3A) it can be assumed that Antibody 20B2-1B12 recognized ca 800000 sites on each parasite. We concluded therefore that it should be possible to detect very small quantities of $B$. ostreae with this antibody.

\section{DISCUSSION}

Bonamia ostreae is a protozoan provisionally belonging to the phylum Ascetospora which contains several important pathogens of bivalve molluscs. This intracellular parasite has not been cultivated in vitro since permissive cell lines for this and other bivalve pathogens do not exist.

Before it was possible to produce specific antibodies to the parasite, it was necessary to develop a protocol for the purification of Bonamia ostreae from infected oyster tissue to obtain the necessary relatively large quantities of purified and concentrated parasite anti-
Fig. 2. Monoclonal antibodies against Bonamia ostreae. (A) Immunological and (B) cellular specificities of 2 purified antibodies from ascite fluids. (A) Radiolabelled monoclonal antibodies 20B2-1B12 and 15C2-2F2 incubated with purified $B$. ostreae adsorbed to nitrocellulose. Each of the antibodies was incubated alone (1), or in the presence of mouse immunoglobulin (2), or in the presence of the unlabelled homologous antibody (3) at a 100-fold greater concentration. (B) The radiolabelled monoclonal antibodies 20B2-1B12 and 15C2-2F2 were incubated on either purified $B$. ostreae (4) or hemolymph of non-parasitized oysters (5) adsorbed to nitrocellulose
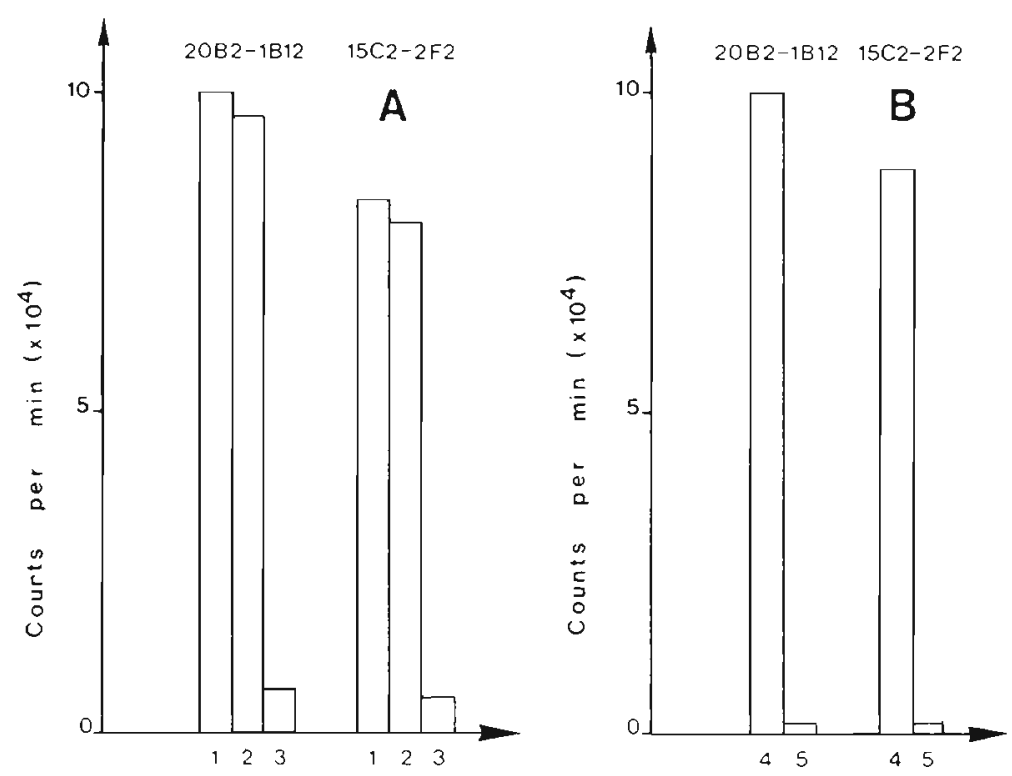

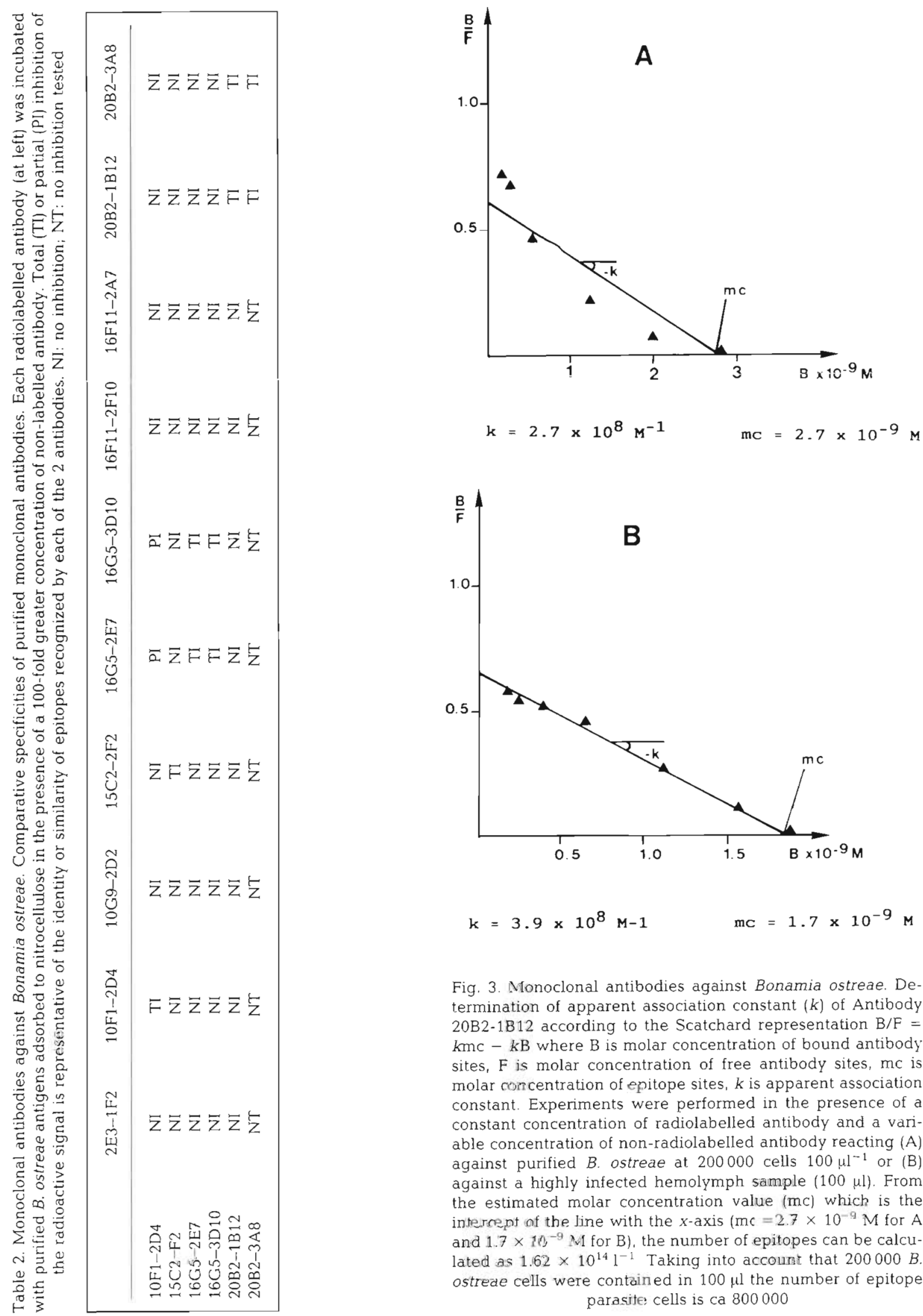

Fig. 3. Monoclonal antibodies against Bonamia ostreae. Determination of apparent association constant $(k)$ of Antibody 20B2-1B12 according to the Scatchard representation $\mathrm{B} / \mathrm{F}=$ $k \mathrm{mc}-k \mathrm{~B}$ where $\mathrm{B}$ is molar concentration of bound antibody sites, $F$ is molar concentration of free antibody sites, mc is molar concentration of epitope sites, $k$ is apparent association constant. Experiments were performed in the presence of a constant concentration of radiolabelled antibody and a variable concentration of non-radiolabelled antibody reacting (A) against purified $B$. ostreae at 200000 cells $100 \mu l^{-1}$ or (B) against a highly infected hemolymph sample $(100 \mu \mathrm{l})$. From the estimated molar concentration value $(\mathrm{mc})$ which is the intercept of the line with the $x$-axis $\left(\mathrm{mc}=2.7 \times 10^{-9} \mathrm{M}\right.$ for $\mathrm{A}$ and $1.7 \times 10^{-9} \mathrm{M}$ for $\mathrm{B}$ ), the number of epitopes can be calculated as $1.62 \times 10^{14} 1^{-1}$ Taking into account that $200000 B$. ostreae cells were contained in $100 \mu$ the number of epitope parasite cells is ca 800000 
gens. It was then possible to produce polyclonal antibodies with sufficient specificity to the parasite for use in indirect immunofluorescence tests (Mialhe et al. 1988) after absorption with acetone extracts of normal oyster tissue. However, antibodies derived from such immune sera were not suitable for direct or indirect enzymatic immunoassays (ELISA) (Schönherr \& Houwink 1984). This was due to a very low concentration of antibodies or to their weak affinity for these parasite antigens. It is essential for an ELISA assay to have antibodies of high specific affinity when the concentration of antigen is very low (Schönherr \& Houwink 1984). For a long-term epidemiological survey program, it is necessary to produce a large quantity of antibodies with a standard titer. A large variation of antibody production in mice makes this impossible which led us to production of monoclonal antibodies in order to fulfill our objectives.

The indirect immunofluorescence technique is currently used for the screening of hybridoma supernatants for specificity to infectious disease agents (Danforth et al. 1982, Steiger \& Seebeck 1986, Laxer et al. 1987). However the labor intensive immunofluorescent method is not practical, when using the precloning method (advantages of which are discussed by Paolucci 1983), because a very large number of wells must be seeded and screened. The screening method, based on the solid phase direct RIA appeared well adapted since it permitted a quick analysis of several hundreds of hybridomas. Moreover, because even after purification the parasites have fragments of parasitophorous vacuole attached to their surface, the screening was performed in 2 steps, the hybridomas producing antibodies against the interfering host cell antigens being previously eliminated.

According to our available information, this work represents the first production of MAbs against a parasite belonging to the phylum Ascetospora. Previous studies have reported the production of MAbs to protozoan parasites of man and domestic animals belonging to the Apicomplexa and Sarcomastigophora (MC Mahon-Pratt et al. 1982, Jaffe \& McMahon-Pratt 1983, Anthony et al. 1985) protozoan phyla. The results of this study are also important in the field of general marine invertebrate pathology because they demonstrate that relatively simple, specific and sensitive diagnostic tests could be produced and should be useful to prevent and manage the dissemination of infectious diseases in cultivated marine invertebrates.

Acknowledgements. The authors are grateful to Mrs MarieJosé Le Goguic for her technical assistance and to Dr Marc Puygrenier for his contribution for the development of this work. Pierre Sai, from National Veterinary School, is sincerely acknowledged for his suggestions and advices.

\section{LITERATURE CITED}

Anthony, R. L., Williams, K. M., Sacci. J. B., Rubin, D. C. (1985). Subcellular and taxonomic specificity of monoclonal antibodies to new world Leishmania. Am. J. trop. Med. Hyg. 34: 1085-1094

Bannister, C., Key, D. (1982). Bonamia, a new threat to the native oyster fishery. Fish. Nat., MAFF Direct. Fish. Res. Lowestoft, pp. 9

Butt, W. R. (1984). Problems of iodination. In: Butt, W R. (ed.) Practical immunoassay. Dekker, New York, p. 19-35

Danforth, H. D., Campbell, G. H., Leef, M. F., Beaudouin, R. L. (1982). Production of monoclonal antibodies by hybridomas sensitized to sporozoites of Plasmodium berghei. J. Parasitol. 68: 1029-1033

Dinamani, P., Hine, M., Jones, J. B. (1987). Occurence and characteristics of the hemocyte parasite Bonamia sp. on the New Zealand dredge oyter Tiostrea lutaria. Dis. aquat. Org. 3: $37-44$

Elston, R. A., Farley, C. A., Kent, M. L. (1986). Occurence and significance of bonamiasis in European flat oyster Ostrea edulis in North America. Dis. aquat. Org. 2: 49-54

Farley, C. A., Wolf, P. H., Elston, R. A. (1988). A long-term study of 'Microcell' disease in oysters with a description of a new genus, Mickrocytos (g. n.), and two new species, Mickrocytos mackini (sp. n.) and Mickrocytos roughleyi (sp. n.). Fish. Bull. U.S. 86: 581-593

French, D., Fischberg, E., Buhl, S., Scharff, M. D. (1986). The production of more useful monoclonal antibodies. I. Modifications of the basic technology. Immunology today II: 344-346

Grizel, H. (1985). Etude des récentes épizooties de l'huitre plate Ostrea edulis Linne et de leur impact sur l'ostréiculture bretonne. Thèse doctorat d'Etat en Sciences Naturelles, Université de Montpellier, Montpellier

Jaffe, C. L., McMahon-Pratt, D. (1983). Monoclonal antibodies specific for Leishmania tropica. J. Immunol. 131. 1987-1934

Laxer, M. A., Healey, M. C., Youssef, N. N. (1987). Production of monoclonal antibodies specific for Eimeria tenella microgametes. J. Parisitol. 73: 611-616

McMahon-Pratt, D., Bennet, E., David, J. R. (1982). Monoclonal antibodies that distinguish subspecies of Leishmania braziliensis. J. Immunol. 129: 926-927

Mialhe, E., Bachère, E., Chagot, D., Grizel, H. (1988). Isolation and purification of the protozoan Bonamia ostreae (Pichot et al, 1979), a parasite affecting the flat oyster Ostrea edulis L. Aquaculture 71 293-299

Paolucci, F. (1983). Optimisation des techniques de préparation des anticorps monoclonaux par hybridation lymphocytaire. Rapport de DEA, Option Immunologie, Université de Montpellier, Montpellier

Paolucci, F., Basuyaux, B., Clavies, C., Piechacsyck, M., Pau, B. (1986), Lymphocyte hybridization: basic principles and selection of monoclonal antibodies directed against hormones. Serono Symposia Publications, Raven Press, 30 : 3-13

Pichot, Y., Comps, M., Tigé, G., Grizel, H., Rabouin, M. A. (1980). Recherche sur Bonamia ostreae gen. n., sp. n., parasite nouveau de l'huitre plate Ostrea edulis L. Revue Trav. Inst. scient. tech. Pêch. marit. 43: 131-140

Polanco, E., Montes, J., Outon, M. J., Melendez, M. I. (1984). Situation pathologique du stock d'huitres plates en Galice (Espagne) en relation avec Bonamia ostreae. Haliotis, Paris 14: 91-95

Schönherr, O. T., Houwink, E. H. (1984). Antibody engineering, a strategy for the development of monoclonal anti- 
bodies. Antonie Van Leeuwenhock, J. Microbiol. 50: $597-623$

Steiger, J., Seebeck, T (1986). Monoclonal antibodies against a $60 \mathrm{KDa}$ phenothiazine-binding protein from Trypanosoma brucei trypanosome species. Mol. biochem. Parasitol. 21. $37-45$

Responsible Subject Editor: A. K Sparks, Seattle, Washington, USA
Van Banning, P. (1982). Some aspects of the occurence, importance and control of the oyster pathogen Bonamia ostreae in the Dutch oyster culture. In: Proc. 3rd int. Coll. Invertebr. Pathol., Brighton, p. 261-265

Walker, W. H. C. (1977). An approach to immunoassays. Clin. Chem. 23: 384402

Manuscript first received: September 13, 1989

Revised version accepted: April 10, 1991 